\title{
Phylogenetic analysis of betanodavirus isolates from Australian finfish
}

\author{
N. J. G. Moody ${ }^{1,3, *}$, P. F. Horwood ${ }^{1}$, A. Reynolds ${ }^{1}$, T. J. Mahony ${ }^{2}$, \\ I. G. Anderson ${ }^{1}$, H. J. Oakey ${ }^{1}$ \\ ${ }^{1}$ Tropical and Aquatic Animal Health Laboratory, Department of Primary Industries and Fisheries, \\ 180-202 River Boulevard, Townsville, Queensland 4810, Australia \\ ${ }^{2}$ Molecular Biosciences Technologies, Department of Primary Industries and Fisheries, \\ 306 Carmody Road, St Lucia, Queensland 4067, Australia \\ ${ }^{3}$ Present address: Australian Animal Health Laboratory, CSIRO Livestock Industries, \\ Private Bag 24, Geelong, Victoria 3220, Australia
}

\begin{abstract}
In Australia, disease caused by betanodavirus has been reported in an increasing number of cultured finfish since the first report of mortalities in 1990. Partial coat protein gene sequences from the T2 or T4 regions of 8 betanodaviruses from barramundi Lates calcarifer, sleepy cod Oxyeleotris lineolata, striped trumpeter Latris lineata, barramundi cod Cromileptes altivelis, Australian bass Macquaria novemaculata and gold-spotted rockcod Epinephelus coioides from several Australian states were determined. Analysis of the 606 bp nucleotide sequences of the T2 region of 4 isolates demonstrated the close relationship with isolates from the red-spotted grouper nervous necrosis virus (RGNNV) genotype and the Cluster Ia subtype. Comparison of a smaller $289 \mathrm{bp}$ sequence from the T4 region identified 2 distinct groupings of the Australian isolates within the RGNNV genotype. Isolates from barramundi from the Northern Territory, barramundi, sleepy cod, barramundi cod and gold-spotted rockcod from Queensland, and striped trumpeter from Tasmania shared a 96.2 to $99.7 \%$ nucleotide identity with each other. These isolates were most similar to the RGNNV genotype Cluster Ia. Isolates from Australian bass from New South Wales and from barramundi from South Australia shared a 98.6\% sequence identity with each other. However, these isolates only shared an 85.8 to $87.9 \%$ identity with the other Australian isolates and representative RGNNV isolates. The closest nucleotide identity to sequences reported in the literature for the New South Wales and South Australian isolates was to an Australian barramundi isolate (Ba94Aus) from 1994. These 2 Australian isolates formed a new subtype within the RGNNV genotype, which is designated as Cluster Ic.
\end{abstract}

KEY WORDS: Betanodavirus · Phylogeny · Nervous necrosis virus · Coat protein · Nodavirus Molecular detection

Resale or republication not permitted without written consent of the publisher

\section{INTRODUCTION}

Viral nervous necrosis (VNN) or viral encephalopathy and retinopathy (VER) is caused by viruses of the Betanodavirus genus of the Family Nodaviridae and has been reported from over 40 fish species worldwide (reviewed by Munday et al. 2002). The disease is characterised by a vacuolating necrosis of neuronal cells of the spinal cord, brain and retina. Mortalities are most commonly observed in cultured larvae, fry and juvenile marine finfish, although the disease has been reported in adult sea bass Dicentrarchus labrax (Le Breton et al. 1997) and a number of freshwater finfish species (Hegde et al. 2003, Athanassopoulou et al. 2004). In Australia, VNN has been associated with cultured barramundi Lates calcarifer since picorna- 
like viral particles were first reported to be associated with degenerative areas of the brain and retina of larvae which had exhibited abnormal swimming behaviour (Glazebrook et al. 1990, Munday et al. 1992). The close antigenic relationship of the picorna-like virus in diseased barramundi to the betanodavirus of striped jack nervous necrosis virus (SJNNV) was reported after specific fluorescence was observed in barramundi tissue using anti-SJNNV rabbit serum in an indirect fluorescence antibody test (Munday et al. 1994). Amplification and sequencing of the T4 region of the coat protein gene of an isolate from barramundi from Australia (Ba94Aus) confirmed betanodavirus as the causative agent (Nishizawa et al. 1997). Virions are small (25 to $30 \mathrm{~nm})$, non-enveloped, icosahedral in shape, and contain single-stranded, bipartite positive sense RNA. The larger RNA segment (RNA1, $3.1 \mathrm{~kb}$ ) encodes a nonstructural protein of $\sim 110 \mathrm{kDa}$, while the smaller RNA segment (RNA2, $1.4 \mathrm{~kb}$ ) encodes the $42 \mathrm{kDa}$ coat protein (Mori et al. 1992, Murphy et al. 1995, Nagai \& Nishizawa 1999, Skliris et al. 2001). The RNA2 coat protein gene is the most common target for reverse transcription polymerase chain reaction (RT-PCR) as this represents the highly conserved area of the viral genome (Nishizawa et al. 1994, Thiéry et al. 1999, Grotmol et al. 2000, Skliris et al. 2001, Gagné et al. 2004, Gomez et al. 2004). While a number of studies have compared betanodavirus isolates by virus neutralization tests (Skliris et al. 2001, Chi et al. 2003, Mori et al. 2003, Shieh \& Chi 2005) or cross-species infectivity trials (Arimoto et al. 1993, Totland et al. 1999), most comparative analyses of isolates have been based on phylogenetic analysis of complete or partial coat protein gene sequences derived from RNA2. Partial sequences have been generated using primers to target the $\mathrm{T} 2$, or the smaller, more variable internal $\mathrm{T} 4$ region of the coat protein gene described by Nishizawa et al. (1994). Originally, Nishizawa et al. (1995) determined (from sequencing of the $\mathrm{T} 2$ region of the coat protein genes) that piscine betanodaviruses isolated in Japan were significantly different from isolates from insects and proposed that these isolates be put into a new genus, Betanodavirus, in the Family Nodaviridae. Analysis of a further 25 finfish betanodavirus isolates identified 4 discrete genotypes that were defined as striped jack nervous necrosis virus (SJNNV), tiger puffer nervous necrosis virus (TPNNV), barfin flounder nervous necrosis virus (BFNNV) and red-spotted grouper nervous necrosis virus (RGNNV) (Nishizawa et al. 1997). As additional isolates were identified in new species or from new geographic locations, there has been general agreement on these 4 genotypes (Dalla Valle et al. 2001, Skliris et al. 2001, Johnson et al. 2002, Chi et al. 2003, Hegde et al. 2003, Thiéry et al. 2004,
Cutrín et al. 2007). However, more recent nucleotide sequencing of the coat protein gene of additional betanodavirus isolates has led to proposals for an Atlantic cod nervous necrosis virus (ACNNV) genotype (Gagné et al. 2004) and a turbot betanodavirus (TNV) genotype (Johansen et al. 2004). Thiéry et al. (2004) have proposed a nonhost name derived nomenclature (Cluster I, II, III and IV).

Within Australia, increased awareness of the disease, improvements in hatchery biosecurity and a reduction in stocking density have significantly reduced mortalities in subsequent batches of larvae compared to those initially observed (Glazebrook \& Heasman 1992, Munday et al. 1992, Anderson et al. 1993). However, as aquaculture of new species has expanded, so has the occurrence of VNN. In this paper, we describe the phylogenetic comparison of partial coat protein gene sequences from the $\mathrm{T} 2$, or the smaller T4 region, of endemic Australian betanodavirus isolates from different finfish species from several geographic regions. We also discuss relationships with sequences reported in the literature.

\section{MATERIALS AND METHODS}

Betanodavirus isolates. Betanodavirus isolates from Queensland, Australia, were obtained from laboratory submissions during routine disease investigations between 1999 and 2005. Samples from the Northern Territory and Tasmania were obtained during a collaborative research project (Moody et al. 2004), while those from New South Wales and South Australia were obtained during investigations into VNN outbreaks in these states. With the exception of the striped trumpeter sample from Tasmania, all isolates were obtained from larvae or juvenile finfish that were exhibiting clinical signs of VNN. Confirmation of infection was determined by observation of vacuolation in the brain and retina by light microscopy and positive immunohistochemistry (IHCT) using sheep anti-barramundi nervous necrosis virus (BNNV) recombinant coat protein polyclonal antibodies. The striped trumpeter isolate was obtained from a broodstock blood sample after nested RT-PCR testing as described below. The location of betanodavirus isolates and species details are outlined in Table 1.

Sample preparation. Heads were aseptically removed from fish and homogenised in an equal volume of Medium 199 (Trace Scientific), supplemented with $500 \mathrm{U}$ benzylpenicillin $\mathrm{ml}^{-1}, 500 \mathrm{\mu g}$ streptomycin sulphate $\mathrm{ml}^{-1}$ and $2 \mu \mathrm{g}$ amphotericin B $\mathrm{ml}^{-1}$. The homogenate was clarified by centrifugation at $10000 \times g$ for $10 \mathrm{~min}$. The striped trumpeter blood sample was frozen and thawed once, incubated with 
an equal volume of sterile deionised water for $60 \mathrm{~min}$ at $5^{\circ} \mathrm{C}$, and clarified by centrifugation at $10000 \times g$ for $10 \mathrm{~min}$. Clarified supernatants were stored at $-80^{\circ} \mathrm{C}$ until tested.

RT-PCR amplification of the T2 region. The T2 RTPCR was established specifically for the phylogenetic analysis of selected isolates. RNA was extracted from $200 \mu \mathrm{l}$ of clarified homogenate from 4 Queensland betanodavirus isolates (T99180614, T342514, T442286 and T540844) using the High Pure viral RNA kit (Roche) according to the manufacturer's instructions, incubated at $90^{\circ} \mathrm{C}$ for $5 \mathrm{~min}$, then stored in ice prior to RT-PCR. RT-PCR was undertaken using the F1 (5'GGA TTT GGA CGT GCG ACC AA-3') primer described by Grotmol et al. (2000) and the NR3 (5'-GGA TTT GAC GGG GCT GCT CA-3') primer described by Thiéry et al. (1999) to produce an amplicon of $~ 830 \mathrm{bp}$ from the T2 region of the coat protein gene. Reverse transcription was conducted at $42^{\circ} \mathrm{C}$ for $60 \mathrm{~min}$ in a $20 \mu \mathrm{l}$ volume containing $2 \mu \mathrm{l}$ of $10 \times$ StrataScript buffer (Integrated Sciences), 20 U StrataScript RT (Integrated Sciences), $0.5 \mathrm{mM}$ of each dNTP (Integrated Sciences), 5 U RNasin (Promega), 1.0 $\mathrm{MM}$ NR3 primer, RNase-free water and $9.5 \mu \mathrm{l}$ RNA template. PCR amplification was carried out in a $50 \mu \mathrm{l}$ reaction mix containing $5 \mu \mathrm{l}$ of the RT reaction, $0.2 \mu \mathrm{M}$ of each primer, $2.5 \mathrm{mM} \mathrm{MgCl}_{2}$ and $25 \mu \mathrm{l}$ HotStarTaq Master Mix (Qiagen). Thermal cycling was conducted in an Eppendorf Mastercycler programmed as follows: 1 cycle at $95^{\circ} \mathrm{C}$ for $15 \mathrm{~min}, 30$ cycles at $95^{\circ} \mathrm{C}$ for $40 \mathrm{~s}, 50^{\circ} \mathrm{C}$ for $40 \mathrm{~s}$ and $72^{\circ} \mathrm{C}$ for $40 \mathrm{~s}$, and 1 cycle at $72^{\circ} \mathrm{C}$ for $10 \mathrm{~min}$. RT-PCR products were resolved using $1.5 \%$ TAE-buffered agarose gel electrophoresis.

RNA extraction and nested RT-PCR of the T4 region. The nested $\mathrm{RT}-\mathrm{PCR}$ of the $\mathrm{T} 4$ region has been in routine diagnostic use at the Tropical and Aquatic Animal Health Laboratory for nodavirus detection since 1999. Over 215 positive and 140 negative reference samples have been used for test optimisation and validation (N. J. G. Moody unpubl. data). To improve efficiency, only nested RT-PCR products are analysed using agarose gel electrophoresis. RNA was extracted from $200 \mu \mathrm{l}$ of clarified homogenate using the High Pure viral RNA kit (Roche) according to the manufacturer's instructions, incubated at $90^{\circ} \mathrm{C}$ for $5 \mathrm{~min}$, then stored in ice prior to RT-PCR. RT-PCR was performed using the F2 (5'-CGT GTC AGT CAT GTG TCG CT-3') and R3 (5'-CGA GTC AAC ACG GGT GAA GA-3') primer set and the method described by Nishizawa et al. (1994) to amplify the T4 region of the coat protein gene, with the following modifications: reverse transcription was conducted at $42^{\circ} \mathrm{C}$ for $60 \mathrm{~min}$ in a $20 \mu \mathrm{l}$ volume containing $2 \mu$ l of $10 \times$ StrataScript buffer (Integrated Sciences), 20 U StrataScript RT (Integrated Sciences), $0.5 \mathrm{mM}$ of each dNTP (Integrated Sciences),
5 U RNasin (Promega), 1.0 $\mu \mathrm{M}$ R3 primer, RNase-free water and $9.5 \mu \mathrm{l}$ RNA template. PCR amplification was carried out in a $50 \mu \mathrm{l}$ reaction mix containing $5 \mu \mathrm{l}$ of the $\mathrm{RT}$ reaction, $0.2 \mu \mathrm{M}$ of each primer, $2.5 \mathrm{mM} \mathrm{MgCl}_{2}$ and $25 \mu \mathrm{l}$ HotStarTaq Master Mix (Qiagen). Thermal cycling was conducted in an Eppendorf Mastercycler programmed as follows: 1 cycle at $95^{\circ} \mathrm{C}$ for $15 \mathrm{~min}$, 30 cycles at $95^{\circ} \mathrm{C}$ for $40 \mathrm{~s}, 50^{\circ} \mathrm{C}$ for $40 \mathrm{~s}$ and $72^{\circ} \mathrm{C}$ for $40 \mathrm{~s}$, and $1 \mathrm{cycle}$ at $72^{\circ} \mathrm{C}$ for $10 \mathrm{~min}$. Nested PCR was performed using the NF2 (5'-GTT CCC TGT ACA ACG ATT CC-3') and NR3 (5'-GGA TTT GAC GGG GCT GCT CA-3' primer set and the method described by Thiéry et al. (1999), with the following modifications: amplification was carried out in a $50 \mu$ reaction mix containing $1 \mu$ of the RT-PCR reaction, $1.0 \mu \mathrm{M}$ of each nested primer, $25 \mu$ HotStarTaq Master Mix (Qiagen) and RNase-free water. Thermal cycling was conducted in an Eppendorf Mastercycler programmed as follows: 1 cycle at $95^{\circ} \mathrm{C}$ for $15 \mathrm{~min}, 25$ cycles at $94^{\circ} \mathrm{C}$ for $40 \mathrm{~s}, 50^{\circ} \mathrm{C}$ for $40 \mathrm{~s}$ and $72^{\circ} \mathrm{C}$ for $40 \mathrm{~s}$, and 1 cycle at $72^{\circ} \mathrm{C}$ for $10 \mathrm{~min}$. Nested RT-PCR products were resolved using $2 \%$ TAE-buffered agarose gel electrophoresis.

Sequencing and phylogenetic analysis. Amplicons generated by amplification of the T2 region of 4 isolates (T99180614, T342514, T442286 and T540844) were ligated into the pGEM-T Easy Vector system (Promega) and cloned using JM109 competent cells according to the manufacturer's instructions. Clones were checked for the correct insert using the T2 PCR, and plasmids were amplified and purified for sequencing. Nucleotide sequencing was conducted using the Big Dye 3.1 sequencing chemistry (Applied Biosystems) with M13 forward and reverse primers. Three clones were sequenced for each isolate. The nucleotide sequences were analysed using Sequencher V4.0.5 (Gene Codes), and the consensus sequence for each isolate was determined from replicate sequences in the forward and reverse directions (National Centre for Biotechnology Information GenBank accession numbers for these sequences are provided in Table 1). Nucleotide sequence information for 4 betanodavirus isolates (T156700, T256901, T451722 and T452934) were obtained by direct sequencing of the amplicon produced from the nested RT-PCR targeting an internal region of the T4 region of the coat protein gene. Representative sequences of non-Australian derived betanodavirus isolates (Table 1) were obtained from BLASTn searches of GenBank for comparison and all sequences were manually aligned using GeneDoc (Nicholas et al. 1997). Phylogenetic trees were determined using the neighbour-joining method, with the bootstrap consensus tree being inferred from 1000 replicates in MEGA 3.1 (Kumar et al. 2004). Evolutionary distances were computed using the maximum composite likelihood method. 


\section{RESULTS}

\section{RT-PCR amplification of partial T2 and T4 regions}

The T2 RT-PCR produced amplicons of the expected size of $\sim 832 \mathrm{bp}$ for the 4 Queensland isolates (T99180614, T342514, T442286 and T540844) tested (data not shown). The nested RT-PCR protocol produced amplicons of the expected size ( 295 bp; Fig. 1) for the 7 diseased fish samples tested and the blood sample from the broodstock striped trumpeter.

\section{Sequence and phylogenetic analysis}

Partial nucleotide sequences of the T2 or T4 region of the betanodavirus coat protein gene from 8 Australian betanodavirus isolates were determined in this study. The GenBank accession numbers are contained in Table 1 . Sequences covering $832 \mathrm{bp}$ of the $\mathrm{T} 2$ region were determined for T99180614, T342514 and T442286, while a 606 bp sequence was determined for T540844; thus, all sequences were reduced to $606 \mathrm{bp}$ for comparison. These sequences shared a 96.9 to

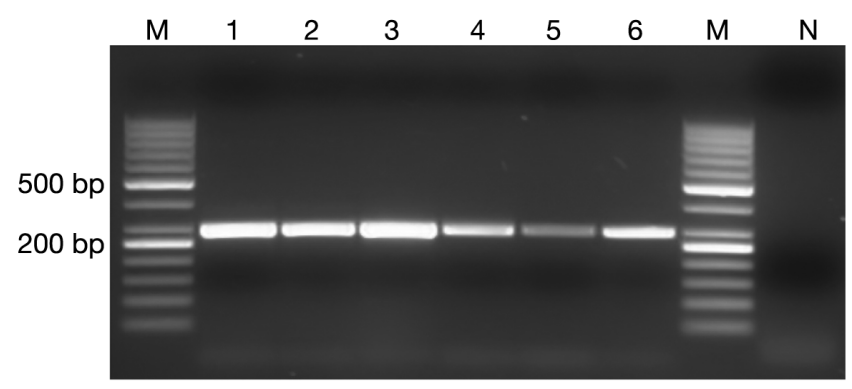

Fig. 1. Nested RT-PCR results (partial T4 region) for Australian betanodavirus isolates obtained from finfish. Lane $\mathrm{M}$ : GeneRuler 50 bp DNA ladder (MBI Fermentas); Lane 1: T342514; Lane 2: T99180614; Lane 3: T442286; Lane 4: T451722; Lane 5: T452934; Lane 6: T450844; Lane N: negative control

Table 1. Details of nodavirus isolates used in the present study

\begin{tabular}{|c|c|c|c|c|}
\hline $\begin{array}{l}\text { Strain } \\
\text { designation }\end{array}$ & $\begin{array}{l}\text { GenBank } \\
\text { accession }\end{array}$ & Host species & $\begin{array}{c}\text { Location } \\
\text { (Year) }\end{array}$ & Source \\
\hline T156700 & EF591367 & Barramundi Lates calcarifer & NT, Aust. (2001) & Present article \\
\hline T256901 & EF591370 & Striped trumpeter Latris lineata & TAS, Aust. (2002) & Present article \\
\hline T342514 & EF591372 & Barramundi L. calcarifer & QLD, Aust. (2003) & Present article \\
\hline T442286 & EF591371 & Barramundi cod Cromileptes altivelis & QLD, Aust. (2004) & Present article \\
\hline T451722 & EF591365 & Australian bass Macquaria novemaculata & NSW, Aust. (2004) & Present article \\
\hline T452934 & EF591366 & Barramundi L. calcarifer & SA, Aust. (2004) & Present article \\
\hline T540844 & EF591369 & Goldspotted rockcod Epinephelus coioides & QLD, Aust. (2005) & Present article \\
\hline T99180614 & EF591368 & Sleepy cod Oxyeleotris lineolata & QLD, Aust. (1999) & Present article \\
\hline 03-160 & AJ698113 & Senegalese sole Solea senegalensis & Spain (2003) & Thiéry et al. (2004) \\
\hline ACNNV & AF445800 & Atlantic cod Gadus morhua & Canada (1999) & Johnson et al. (2002) \\
\hline AH95NorA & AJ254641 & Halibut Hippoglossus hippoglossus & Norway (1995) & Grotmol et al. (2000) \\
\hline AHNNV & AF160473 & Halibut $H$. hippoglossus & Norway (1995) & Aspenhaug et al. (1999) \\
\hline Ba94Aus & - & Barramundi L. calcarifer & Australia (1994) & Nishizawa et al. (1997) \\
\hline BB09 & AJ698094 & Sea bass Dicentrarchus labrax & France (2003) & Thiéry et al. (2004) \\
\hline BF93Hok & D38635 & Barfin flounder Verasper moseri & Japan (1993) & Gagné et al. (2004) \\
\hline Cod02ac2 & AY547547 & Atlantic cod Gadus morhua & Canada (2002) & Gagné et al. (2004) \\
\hline DGNNV & AF245004 & Giant grouper E. lanceolatus & Taiwan & Lin et al. (2001) \\
\hline DlEV & Y08700 & Sea bass Dicentrarchus labrax & Greece & Sideris (1997) \\
\hline Dlev-Fr & U39876 & European seabass D. labrax & France (1997) & Gagné et al. (2004) \\
\hline ETNNV & AF318942 & Greasy grouper E. tauvina & Singapore & Tan et al. (2001) \\
\hline GNNV & AF499774 & Guppy Poicelia reticulata & Singapore (2000) & Hegde et al. (2003) \\
\hline JF93Hir & D38527 & Japanese flounder Paralichthys oliveatus & Japan (1993) & Nishizawa et al. (1997) \\
\hline MGNNV & AF245003 & Malabar grouper E. malabaricus & Taiwan & Lin et al. (2001) \\
\hline RG91Tok & D38636 & Red-spotted grouper E. akaara & Japan (1991) & Nishizawa et al. (1997) \\
\hline SJOri & D30814 & Striped jack Pseudocaranx dentex & Japan (1991) & Nishizawa et al. (1997) \\
\hline SGWak97 & AY324870 & Sevenband grouper E. septemfasciatus & Japan (1997) & Iwamoto et al. (2004) \\
\hline TNV & AJ608266 & Turbot Scophthalmus maximus & Norway & Johansen et al. (2004) \\
\hline TP93Kag & D38637 & Tiger puffer Takifugu rupripes & Japan (1993) & Nishizawa et al. (1997) \\
\hline V67 & AJ698104 & Sea bass $D$. labrax & France (1995) & Thiéry et al. (2004) \\
\hline X199 & AJ698103 & Meagre Argyrosomus regius & France (1999) & Thiéry et al. (2004) \\
\hline Y235 & AJ698105 & Sea bass D. labrax & France (1991) & Thiéry et al. (2004) \\
\hline Y55 & AJ698102 & Sea bass $D$. labrax & France $(2000$ & Thiéry et al. (2004) \\
\hline YGNNV & AF283554 & Yellow grouper E. awoara & Taiwan & Lai et al. (2001) \\
\hline Z233 & AJ698111 & Convict surgeonfish Acanthurus triostegus & Tahiti (2001) & Thiéry et al. (2004) \\
\hline
\end{tabular}


99.7 \% identity with each other. Phylogenetic analysis of the partial T2 region nucleotide sequences, with representative isolates from the different genotypes obtained from GenBank, identified these Australian betanodavirus isolates as members of the RGNNV genotype (Fig. 2). Interestingly, the marine isolates (T342514, T442286 and T540844) clustered together with other marine isolates within this genotype and shared a 98.8 to $99.0 \%$ nucleotide identity with a representative isolate of the RGNNV genotype, RG91Tok. In contrast, the isolate from the freshwater species (T99180614) clustered with an isolate (JF93Hir) from the Japanese flounder. These 2 isolates shared a $97.5 \%$ nucleotide sequence identity.

Sequences of $289 \mathrm{bp}$ were determined after nested RT-PCR amplification of isolates T156700, T256901, T451722 and T452934. Comparison of all the Australian betanodavirus isolates using sequences derived from the $\mathrm{T} 4$ region replicated the results obtained for the T2 region sequences and determined that these 4 isolates were also more closely related to members of the RGNNV genotype than representative isolates from any other genotype (Fig. 3, Table 2). However, sequence analysis of these additional isolates demonstrated that the endemic Australian betanodavirus isolates comprised 2 distinct groups within the RGNNV genotype. One group corresponding to the Cluster Ia subtype described by Thiéry et al. (2004) contained the isolates from barramundi (T342514), barramundi cod (T442286), gold-spotted

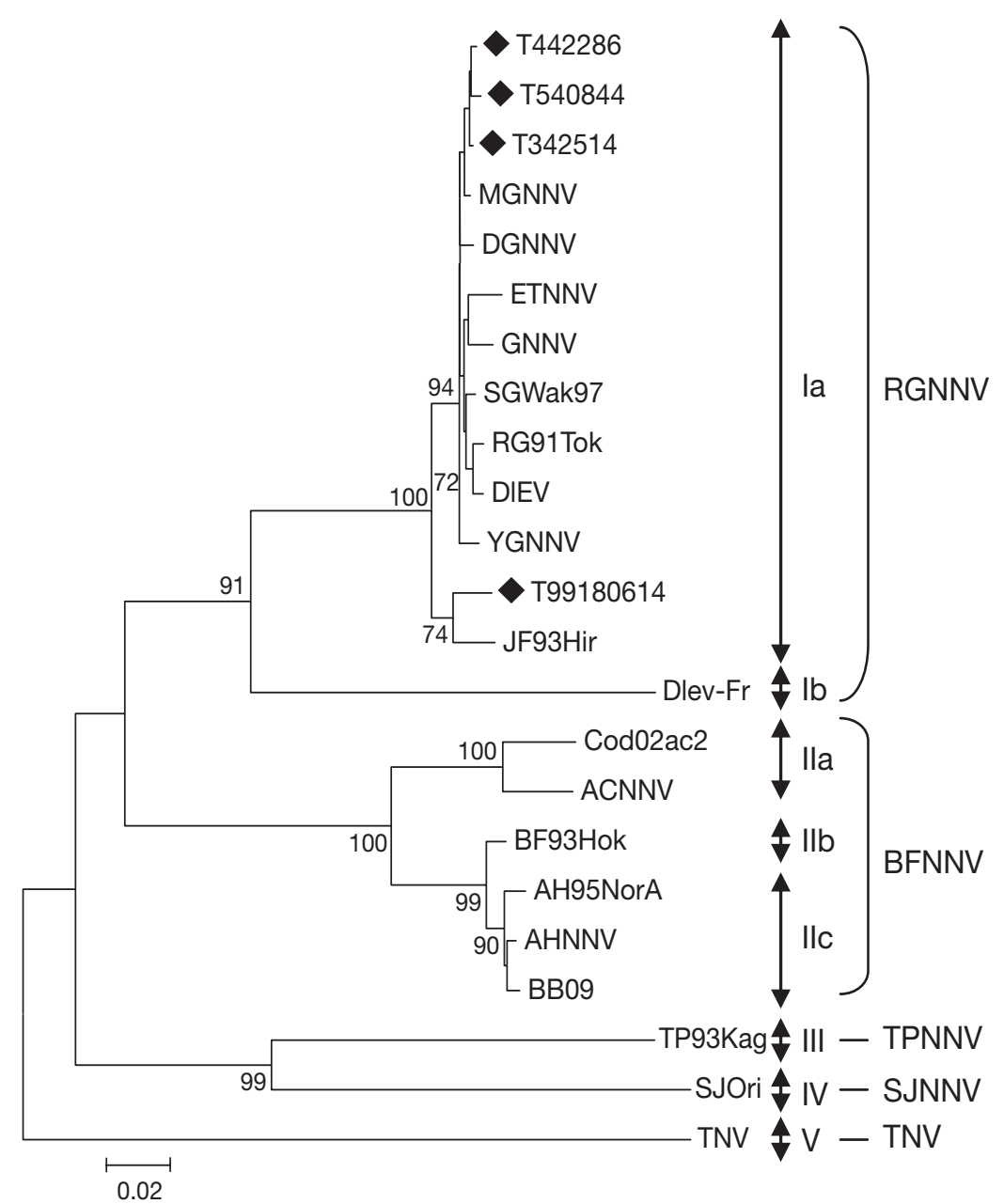

Fig. 2. Unrooted phylogenetic tree produced from the partial betanodavirus nucleotide sequences of the coat protein T2 region showing genotype groupings. See Table 1 for isolate information. ( ) Australian isolates from the present study. Phylogeny was determined using the neighbour-joining method in MEGA 3.1. Numbers indicate bootstrap percentages from 1000 resamplings. Nomenclature of genotypes is based on Nishizawa et al. (1997) and Thiéry et al. (2004). RGNNV: red-spotted grouper nervous necrosis virus; BFNNV: barfin flounder nervous necrosis virus; SJNNV: striped jack nervous necrosis virus; TNV: turbot betanodavirus

Table 2. Percent nucleotide sequence identities of the Australian nodavirus isolates and representative isolates from the literature, based on the $289 \mathrm{bp}$ sequence of the partial T4 region of the coat protein gene. Isolate details are given in Table 1

\begin{tabular}{|c|c|c|c|c|c|c|c|c|}
\hline Isolate & T352514 & $\mathrm{T} 442286$ & T540844 & Т99180614 & T156700 & Т256901 & T452934 & $\mathrm{T} 451722$ \\
\hline RG91Tok & 98.6 & 98.9 & 98.6 & 96.1 & 97.9 & 98.6 & 85.8 & 85.8 \\
\hline Ba94Aus & 83.7 & 83.4 & 83.4 & 83.7 & 84.4 & 83.1 & 94.8 & 94.8 \\
\hline Dlev-Fr & 83.7 & 84.0 & 83.7 & 85.4 & 84.4 & 84.1 & 82.3 & 81.7 \\
\hline BF93Hok & 76.8 & 77.1 & 76.8 & 75.7 & 76.4 & 76.8 & 75.1 & 75.7 \\
\hline AHNNV & 76.4 & 76.8 & 76.4 & 75.4 & 76.1 & 76.5 & 75.4 & 76.1 \\
\hline ACNNV & 74.3 & 74.0 & 74.4 & 75.4 & 73.7 & 73.7 & 75.4 & 75.4 \\
\hline SJOri & 66.7 & 66.4 & 66.0 & 65.7 & 65.4 & 66.1 & 67.1 & 66.4 \\
\hline TP93Kag & 66.7 & 66.4 & 66.1 & 66.7 & 65.4 & 66.7 & 67.1 & 67.1 \\
\hline TNV & 68.8 & 68.8 & 68.5 & 67.8 & 69.2 & 68.8 & 68.2 & 68.2 \\
\hline
\end{tabular}



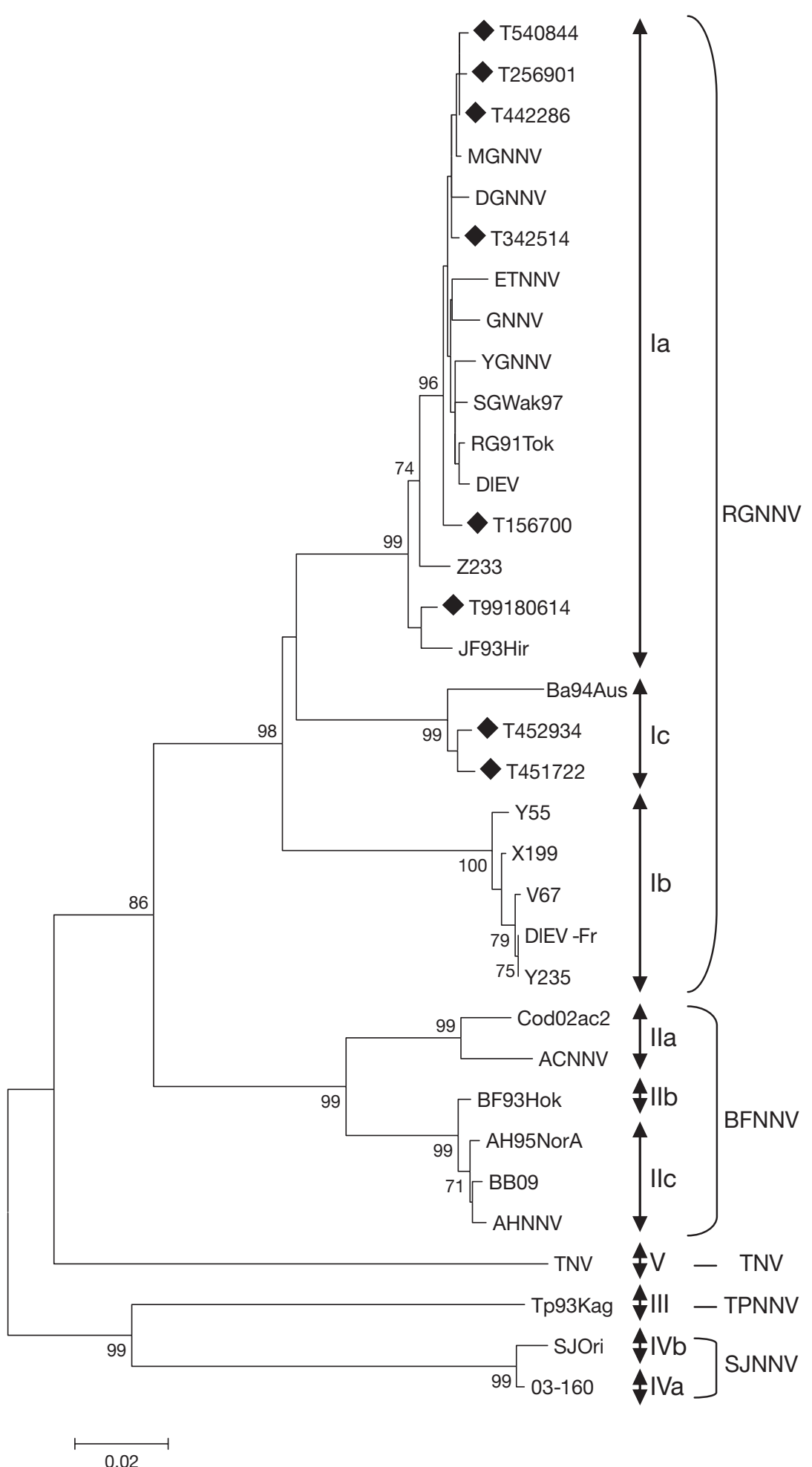

Fig. 3. Unrooted phylogenetic tree produced from the partial betanodavirus nucleotide sequences of the coat protein T4 region showing genotype groupings. See Table 1 for isolate information. ( ) Australian isolates from the present study. Phylogeny was determined using the neighbour-joining method in MEGA 3.1. Numbers indicate bootstrap percentages from 1000 resamplings. Nomenclature of genotypes is based on Nishizawa et al. (1997) and Thiéry et al. (2004). See

Fig. 2 for full virus names rockcod (T540844) and sleepy cod (T99180614) from Queensland, barramundi from the Northern Territory (T156700), and striped trumpeter from Tasmania (T256901). All shared a 96.1 to $99.7 \%$ nucleotide homology with each other and with RG91Tok (Table 2). In contrast, while the 2 isolates from Australian bass from New South Wales (T451722) and barramundi from South Australia (T452934) shared 98.6\% nucleotide and 96.8\% deduced amino acid identity with each other, they only shared an 85.8 to $87.9 \%$ nucleotide and 67.3 to $72.9 \%$ deduced amino acid identity with the other Australian isolates (Table 3). T451722 and T452934 shared a much lower nucleotide identity with RG91Tok of only $85.8 \%$ (Table 2 ). Both were most closely related to an Australian barramundi isolate (Ba94Aus) reported by Nishizawa et al. (1997), and these 3 isolates produced a distinct group within the RGNNV genotype (Fig. 3) corresponding to a new subtype, Cluster Ic.

All Australian betanodavirus sequences contained a 6 nucleotide deletion when compared with representative isolates of the SJNNV (SJOri) and TPNNV (TP93Kag) genotypes (Nishizawa et al. 1997) and a recently reported sequence from TNV (Johansen et al. 2004). High bootstrap support values were obtained for the division into the major groupings for the phylogenetic analysis, and construction of phylogenetic trees using maximum parsimony and minimum evolution methods for nucleic acid sequences and deduced amino acid sequences resulted in very similar results (data not shown).

\section{DISCUSSION}

In this paper, we describe the sequence comparisons and phylogenetic relationships of partial nucleic acid and deduced amino acid sequences from the T2 or T4 region of the coat protein gene from 8 betanodavirus isolates from 6 economically impor- 
Table 3. Percent nucleotide sequence (upper right) and deduced amino acid sequence (lower left) identities of the Australian nodavirus isolates, based on the $289 \mathrm{bp}$ sequence of the partial T4 region of the coat protein gene. Isolate details are given in Table 1

\begin{tabular}{|c|c|c|c|c|c|c|c|c|}
\hline Isolate & T352514 & T442286 & T540844 & T99180614 & T156700 & T256901 & T452934 & T451722 \\
\hline \multicolumn{9}{|c|}{ Nucleotide identity (\%) } \\
\hline T342514 & & 99.7 & 99.3 & 96.2 & 98.6 & 99.3 & 86.5 & 86.5 \\
\hline T442286 & 98.9 & & 99.6 & 96.5 & 99.0 & 99.7 & 86.2 & 86.2 \\
\hline T540844 & 97.9 & 99.0 & & 96.2 & 98.6 & 99.3 & 85.8 & 85.8 \\
\hline T99180614 & 91.6 & 92.6 & 91.6 & & 96.9 & 96.2 & 87.2 & 87.9 \\
\hline T156700 & 96.8 & 97.9 & 96.8 & 91.7 & & 98.6 & 86.5 & 86.5 \\
\hline T256901 & 97.8 & 99.0 & 97.9 & 90.6 & 96.8 & & 85.8 & 85.8 \\
\hline T452934 & 70.5 & 69.5 & 68.4 & 71.9 & 69.5 & 68.4 & & 98.6 \\
\hline $\mathrm{T} 451722$ & 69.5 & 68.4 & 67.3 & 72.9 & 68.4 & 67.4 & 96.8 & \\
\hline \multicolumn{9}{|c|}{ Deduced amino acid identity (\%) } \\
\hline
\end{tabular}

tant cultured fish species in Australia. With the exception of the striped trumpeter isolate (T256901), which was obtained using nested RT-PCR testing of broodstock blood, all isolates were from clinically affected fish. The presence of betanodavirus had been determined based on observation of a vacuolating neuronal necrosis in histological sections, previously positive nested RT-PCR test results and/or positive IHCT using polyclonal antibodies raised against the recombinant coat protein prepared from a Queensland barramundi betanodavirus isolate (Moody et al. 2004). All of the Australian betanodavirus isolates were of the RGNNV genotype proposed by Nishizawa et al. $(1995,1997)$, although they occurred in 2 distinct clusters. Those in Cluster Ia, which are described by Thiéry et al. (2004), contained isolates from Queensland (T342541, T540844 and T99180614), the Northern Territory (T156700), and Tasmania (T256901) (Fig. 3). The similarity of the barramundi isolates from Queensland and the Northern Territory is not surprising given their geographic proximity, the natural host range of wild barramundi (Grey 1987), and the degree of translocation of stocks within this region of Australia. The similar geographic distributions of barramundi cod and gold-spotted rockcod probably account for the similarity to these barramundi isolates. They are all from tropical marine fish species. The sleepy cod isolate, although from a tropical species, was obtained from a freshwater facility with no association with marine finfish; no previously reported VNN and no subsequent mortalities have been reported for this species. The source of infection and distribution of this isolate is unknown. The inclusion of the striped trumpeter isolate from Tasmania in the RGNNV genotype, Cluster Ia subtype, is also interesting as this is a cooler water, temperate species (Morehead et al. 2000) and most isolates in this genotype are from tropical species.

The Australian bass isolate from New South Wales (T451722) and the barramundi isolate from South Aus- tralia (T452934) also fell within the RGNNV genotype, although these isolates formed a second distinct cluster, Cluster Ic, with Ba94Aus (Fig. 3). This indicates that within Australia, at least 2 distinct strains of betanodavirus are present and barramundi are susceptible to both. The distinct clustering observed in these isolates is similar to the grouping of isolates from France (X199, Y55, V67 and Y235) that formed a separate subgroup within the RGNNV genotype, which was designated as Cluster Ib (Thiéry et al. 2004). Clustering of isolates within genotypes has also been described after phylogenetic analysis of SJNNV isolates from the Iberian Peninsula, where 2 distinct clusters designated as IVa and IVb were reported (Cutrín et al. 2007). Nylund et al. (2008) identified 3 clusters, which are designated as Atlantic halibut nervous necrosis virus (AHNNV), cod nervous necrosis virus (GMNNV) and ACNNV, within the BFNNV genotype after phylogenetic analysis of betanodavirus isolates from Norway. The 3 BFNNV clusters are very similar to the IIa, IIb and IIC clusters within the BFNNV genotype described by Thiéry et al. (2004), and adopted in Fig. 3. While the T4 nested RT-PCR successfully amplified the appropriate sequence for all isolates tested, the resulting placement of the Australian betanodavirus isolates into 2 distinct subtypes of the RGNNV genotype was unexpected. This highlights the need to routinely sequence amplicons, especially when diagnosis is based solely on results from PCR-based tests, to ensure that any genetic variation can be determined. This is particularly important when nodavirus infection is suspected in a new species or from a new geographic location.

The phylogenetic analysis of partial coat protein gene sequences in this paper agrees with the classification of betanodavirus isolates into at least 5 genotypes (Figs. 2 \& 3) similar to those of previous studies (Nishizawa et al. 1997, Dalla Valle et al. 2001, Skliris et al. 2001, Johnson et al. 2002, Chi et al. 2003, Hegde et al. 2003, Gagné et al. 2004, Johansen et al. 2004, 
Thiéry et al. 2004, Cutrín et al. 2007). These genotypes include the 4 (BFNNV, SJNNV, RGNNV and TPNNV) originally proposed by Nishizawa et al. (1995) and an additional genotype, TNV, proposed by Johansen et al. (2004). Based on the classification system described by Thiéry et al. (2004), the TNV genotype corresponds to Cluster V (Figs. 2 \& 3). Two Australian isolates form a new subtype, Cluster Ic (Fig. 3). Within the Betanodavirus genus, the RGNNV genotype contains isolates from the widest host range (over 20 different species) with the greatest geographic distribution (over 10 countries, or regions, throughout the northern and southern hemispheres) including Asia, Europe, the Mediterranean, the USA (Nishizawa et al. 1995, 1997, Curtis et al. 2001, Dalla Valle et al. 2001, Lin et al. 2001, Skliris et al. 2001, Chi et al. 2003, Hegde et al. 2003, Thiéry et al. 2004) and Australia. The detection of representatives of the other betanodavirus genotypes has been more limited although reporting of isolates in these genotypes is increasing, possibly due to increased awareness of betanodavirus, availability of more sensitive test protocols, and an increase in the number of species cultured. Members of the BFNNV genotype have been detected from at least 5 predominantly colder water species in France, Japan, North America, Norway and Scotland (Nishizawa et al. 1997, Grotmol et al. 2000, Starkey et al. 2000, Johnson et al. 2002, Thiéry et al. 2004). Isolates of the SJNNV genotype were originally found only in 4 species from Japan (Nishizawa et al. 1997) but have subsequently been reported from 5 species in Spain and Portugal (Thiéry et al. 2004, Cutrín et al. 2007). The TPNNV genotype is represented by only one isolate from Takifugu rubripes from Japan (Nishizawa et al. 1997) as is the TNV genotype which is represented by an isolate from an outbreak in Scophthalmus maximus from Norway (Johansen et al. 2004). Amplification and sequencing of the T2 region of additional betanodavirus isolates, including those in this study that could only be sequenced from the partial T4 region, will assist in the determination of genotypic boundaries. Due to improved biosecurity measures and subsequent elimination of the infection, or resource constraints, no confirmatory sampling, testing and sequencing could be undertaken from the facilities where the samples were originally obtained. Sequencing of additional isolates from the same facilities and regions within Australia as those reported in this paper will enhance our knowledge of strain variability within and among species, and clarify the relationships between isolates of the different subtypes within the RGNNV genotype.

Investigations of the relationships between betanodavirus isolates comparing viral RNA1 sequences were limited to isolates from Japan and Singapore, with results being in agreement with RNA2 phylogeny
(Mori et al. 1992, Nagai \& Nishizawa 1999, Tan et al. 2001). However, RNA1 sequences for additional isolates from Europe and the Pacific region have recently been determined and compared (Névarez et al. 2004, Toffolo et al. 2007). Results show that while the RNA1 and RNA2 sequences were of the same genotype for the majority of isolates studied, reassortment between genotypes had occurred in a small number of isolates. As a result, depending on the gene used in the phylogenetic analysis (RNA1 or RNA2), these isolates could be attributed to different genotypes. Therefore, sequencing of both RNA1 and RNA2 is required to completely characterise new isolates. Amplification and sequence comparison of RNA1 of the Australian isolates described in this study is important to clarify the relationships between isolates in the different clusters within the RGNNV genogroup. Sequencing of both genes could also provide early warning of the presence of a previously undetected genotype. However, until a consensus has been reached regarding which RNA strand is more appropriate for phylogenetic classification, and more RNA1 sequences are available, the current standard for phylogenetic determination using RNA2 sequences should be maintained.

Further biological characterisation of the isolates will add important information about the characteristics of the different genotypes. Cross-species infectivity trials have identified differences in susceptibility of certain species to isolates of different genotypes (Totland et al. 1999, Grotmol et al. 2000) and Iwamoto et al. (2004) reported that this host specificity was determined by RNA2. Different optimum growth temperatures in cell culture have been observed for isolates of different genotypes (Iwamoto et al. 2000), and results from neutralisation studies using genotype-specific monoclonal or polyclonal antibodies have identified serotypes that are similar to the genotypes identified by phylogenetic analysis based on the RNA2 gene (Skliris et al. 2001, Chi et al. 2003, Mori et al. 2003). These characteristics have yet to be determined for the majority of the Australian betanodavirus isolates. Full molecular and biological characterisation of betanodavirus isolates, including complete sequencing of the 2 segments of the genome, requires cross-species infectivity trials as well as temperature sensitivity and neutralisation studies. Knowledge of these features will enable optimisation of detection tests and improved management procedures to reduce the impact of these viruses to established and emerging aquaculture facilities and to the environment. More complete characterisation will also assist in determining whether the distinct Clusters Ia, Ib (Thiéry et al. 2004) and Ic, which are observed within the RGNNV genotype, are really subtypes or should be considered as different genotypes. 
Acknowledgements. This work was supported by research grants to I.G.A. (FRDC 1999/201) and N.J.G.M. (FRDC 2001/626) from the Fisheries Research and Development Corporation through the Aquatic Animal Health Subprogram. We thank J. Humphrey (Northern Territory Department of Primary Industries and Fisheries), S. Battaglene (Tasmanian Aquaculture and Fisheries Institute), M. Landos (New South Wales Fisheries) and M. Deveney (Primary Industries Research South Australia) for providing samples. We also thank R. Bowater, K. Condon and N. Levy for assistance with sample submission and molecular testing. I. Diallo, J. Morgan and K. Condon critically reviewed the manuscript.

\section{LITERATURE CITED}

Anderson I, Barlow C, Fielder S, Hallam D, Heasman M, Rimmer M (1993) Occurrence of the picorna-like virus infecting barramundi. Aust Aquacult 7:43-44

Arimoto M, Mori K, Nakai T, Muroga K, Furusawa I (1993) Pathogenicity of the causative agent of viral nervous necrosis disease in striped jack, Pseudocaranx dentex (Bloch \& Schneider). J Fish Dis 16:461-469

Athanassopoulou F, Billinis C, Prapas TH (2004) Important disease conditions of newly cultured species in intensive freshwater farms in Greece; first incidence of nodavirus infection in Acipenser sp. J Fish Dis 60:247-252

Chi SC, Shieh JR, Lin SJ (2003) Genetic and antigenic analysis of betanodaviruses isolated from aquatic organisms in Taiwan. Dis Aquat Org 55:221-228

Curtis PA, Drawbridge M, Iwamoto T, Nakai T, Hedrick RP, Gendron AP (2001) Nodavirus infection of juvenile white sea bass, Atractoscion nobilis, cultured in southern California: first record of viral nervous necrosis (VNN) in North America. J Fish Dis 24:263-271

Cutrín JM, Dopazo CP, Thiéry R, Leao P, Oliveira JG, Barja JL, Bandin I (2007) Emergence of pathogenic betanodaviruses belonging to the SJNNV genotype in farmed fish species from the Iberian Peninsula. J Fish Dis 30:225-232

Dalla Valle L, Negrisolo E, Patarnello P, Zanella L, Maltese C, Bovo G, Colombo L (2001) Sequence comparison and phylogenetic analysis of fish nodaviruses based on the coat protein gene. Arch Virol 146:1125-1137

Gagné N, Johnson SC, Cook-Versloot M, MacKinnon AM, Olivier G (2004) Molecular detection and characterization of nodavirus in several marine fish species from the northeastern Atlantic. Dis Aquat Org 62:181-189

Glazebrook JS, Heasman MP (1992) Diagnosis and control of picorna-like virus infections in larval barramundi, Lates calcarifer Bloch. In: Shariff M, Subasinghe RP, Arthur JR (eds) Diseases in Asian aquaculture. Proc 1st Symp on Diseases in Asian Aquaculture, 26-29 Nov 1990, Bali, Indonesia. Fish Health Section, Asian Fisheries Society, p 267-272

Glazebrook JS, Heasman MP, de Beer SW (1990) Picorna-like viral particles associated with mass mortalities in larval barramundi, Lates calcarifer Bloch. J Fish Dis 13:245-249

Gomez DK, Sato J, Mushiake K, Ishiki T, Okinaka Y, Nakai T (2004) PCR-based detection of Betanodaviruses from cultured and wild marine fish with no clinical signs. J Fish Dis 27:603-608

Grey DL (1987) An overview of Lates calcarifer in Australia and Asia. In: Copland JW, Grey DL (eds) Management of wild and cultured sea bass/barramundi (Lates calcarifer). Proceedings of an Internation Workshop held in Darwin, NT, Australia, 24-30 Sept 1986. ACIAR Proceedings No. 20. Australian Centre for International Agriculture
Research, Canberra, p 15-21

> Grotmol S, Nerland AH, Biering E, Totland GK, Nishizawa T (2000) Characterisation of the capsid protein gene from a nodavirus strain affecting the Atlantic halibut Hippoglossus hippoglossus and design of an optimal reverse-transcriptase polymerase chain reaction (RT-PCR) detection test. Dis Aquat Org 36:95-106

Hegde A, Teh HC, Lam TJ, Sin YM (2003) Nodavirus infection in freshwater ornamental fish, guppy, Poicelia reticulata-comparative characterization and pathogenicity studies. Arch Virol 148:575-586

> Iwamoto T, Nakai T, Mori K, Arimoto M, Furusawa I (2000) Cloning of the fish cell line SSN-1 for piscine nodaviruses. Dis Aquat Org 43:81-89

- Iwamoto T, Okinaka Y, Mise K, Mori KI, Arimoto M, Okuno T, Nakai T (2004) Identification of host-specificity determinants in betanodaviruses by using reassortants between striped jack nervous necrosis virus and sevenband grouper nervous necrosis virus. J Virol 78:1256-1262

Johansen R, Sommerset I, Tørud B, Korsnes K and others (2004) Characterization of nodavirus and viral encephalopathy and retinopathy in farmed turbot, Scophthalmus maximus (L.). J Fish Dis 27:591-601

Johnson SC, Sperker SA, Leggiadro CT, Groman DB and others (2002) Identification and characterization of a piscine neuropathy and nodavirus from juvenile Atlantic cod from the Atlantic coast of North America. J Aquat Anim Health 14:124-133

> Kumar S, Tamura K, Nei M (2004) MEGA3: integrated software for molecular evolutionary genetics analysis and sequence alignment. Brief Bioinform 5:150-163

> Le Breton A, Grisez L, Weetman J, Ollevier F (1997) Viral nervous necrosis (VNN) associated with mass mortalities in cage-reared sea bass, Dicentrarchus labrax (L.). J Fish Dis 20:145-151

> Lin CS, Lu MW, Tang L, Liu W and others (2001) Characterization of virus-like particles assembled in a recombinant baculovirus system expressing the capsid protein of fish nodavirus. Virology 290:50-58

Moody NJ, Horwood PF, McHardy S (2004) Aquatic animal health subprogram: development of diagnostic tests for the detection of nodavirus. Fisheries Research and Development Corporation Project 2001/626 Final Report. Department of Primary Industries and Fisheries, Queensland Government, Brisbane

> Morehead DT, Ritar AJ, Pankhurst NW (2000) Effect of consecutive 9- or 12-month photothermal cycles and handling on sex steroid levels, oocyte development, and reproductive performance in female striped trumpeter Latris lineata (Latrididae). Aquaculture 189:293-305

Mori K, Nakai T, Muroga K, Arimoto M, Mushiake K, Furusawa I (1992) Properties of a new virus belonging to Nodaviridae found in larval striped jack (Pseudocaranx dentex) with nervous necrosis. Virology 187:368-371

- Mori $\mathrm{K}$, Mangyoku T, Iwamoto $\mathrm{T}$, Arimoto M, Tanaka S, Nakai $T$ (2003) Serological relationships among genotypic variants of betanodavirus. Dis Aquat Org 57:19-26

Munday BL, Langdon JS, Hyatt A, Humphrey JD (1992) Mass mortality associated with a viral-induced vacuolating encephalopathy and retinopathy of larvae and juvenile barramundi, Lates calcarifer Bloch. Aquaculture 103: $197-211$

Munday BL, Nakai T, Nguyen HD (1994) Antigenic relationship of the picorna-like virus of larval barramundi, Lates calcarifer Bloch to the nodavirus of larval striped jack, Pseudocaranx dentex (Bloch \& Schneider). Aust Vet J 71: 384-385 
Munday BL, Kwang J, Moody N (2002) Betanodavirus infections of teleost fish: a review. J Fish Dis 25:127-142

Murphy FA, Fauquet CM, Bishop DHL, Ghabrial SA and others (1995) (eds) Virus taxonomy. 6th Rep Int Committee on Taxonomy of Viruses. Springer-Verlag, New York, p 586

Nagai T, Nishizawa T (1999) Sequence of the non-structural protein gene encoded by RNA1 of striped jack nervous necrosis virus. J Gen Virol 80:3019-3022

Névarez L, Cozien J, Thiéry R (2004) Characterization of the RNA-dependent RNA polymerase gene of isolates of viral encephalopathy and retinopathy virus. 6th Int Symp on Viruses of Lower Vertebrates, Hakodate, Japan, 19-22 Sept 2004, p 15

Nicholas KB, Nicholas HB Jr, Deerfield DW II (1997) GeneDoc: analysis and visualization of genetic variation, EMBNEW. NEWS 4:14

Nishizawa T, Mori K, Nakai T, Furusawa I, Muroga K (1994) Polymerase chain reaction (PCR) amplification of RNA of striped jack nervous necrosis virus (SJNNV). Dis Aquat Org 18:103-107

Nishizawa T, Mori K, Furuhashi M, Nakai T, Furusawa I, Muroga K (1995) Comparison of the coat protein genes of five fish nodaviruses, the causative agents of viral nervous necrosis in marine fish. J Gen Virol 76:1563-1569

Nishizawa T, Furuhashi M, Nakai T, Nakai T, Muroga K (1997) Genomic classification of fish nodaviruses by phylogenetic analysis of the coat protein gene. Appl Environ Microbiol 63:1633-1636

Nylund A, Karlsbakk E, Nylund S, Isaken TE and others (2008) New clade of betanodaviruses detected in wild and farmed cod (Gadus morhua) in Norway. Arch Virol 153: 541-547

Shieh JR, Chi SC (2005) Production of monoclonal antibodies against grouper nervous necrosis virus (GNNV) and

Editorial responsibility: John Austin,

Oldendorf/Luhe, Germany development of an antigen capture ELISA. Dis Aquat Org 63:53-60

Skliris GP, Krondiris JV, Sideris DC, Shinn AP, Starkey WG, Richards RH (2001) Phylogenetic and antigenic characterisation of new fish nodavirus isolates from Europe and Asia. Virus Res 75:59-67

> Starkey WG, Ireland JH, Muir KF, Shinn AP, Richards RH, Ferguson HW (2000) Isolation of nodavirus from Scottish farmed halibut, Hippoglossus hippoglossus (L.). J Fish Dis 23:418-422

> Tan C, Huang B, Cheng SF, Ngoh GH, Munday B, Chen SC, Kwang J (2001) Determination of the complete nucleotide sequence of RNA1 and RNA2 from greasy grouper (Epinephelus tauvina) nervous necrosis virus, Singapore strain. J Gen Virol 82:647-653

> Thiéry R, Raymond JC, Castric J (1999) Natural outbreak of viral encephalopathy and retinopathy in juvenile sea bass, Dicentrarchus labrax: study by nested reverse transcriptase-polymerase chain reaction. Virus Res 63:11-17

> Thiéry R, Cozien J, de Boisséson C, Kerbart-Boscher S, Névarez L (2004) Genomic classification of new betanodavirus isolates by phylogenetic analysis of the coat protein gene suggests a low host-fish species specificity. J Gen Virol 85:3079-3087

Toffolo V, Negrisolo E, Maltese C, Bovo G, Belvedere P, Colombo L, Dalla Valle L (2007) Phylogeny of betanodaviruses and molecular evolution of their RNA polymerase and coat proteins. Mol Phylogenet Evol 43:298-308

Totland GK, Grotmol S, Morita T, Nishioka T, Nakai T (1999) Pathogenicity of nodavirus strains from striped jack Pseudocaranx dentex and Atlantic halibut Hippoglossus hippoglossus, studied by waterborne challenge of yolk-sac larvae of both teleost species. Dis Aquat Org 38:169-175

Submitted: September 27, 2007; Accepted: August 13, 2009 Proofs received from author(s): November 9, 2009 